\title{
Urate oxidase knockdown decreases oxidative stress in a murine hepatic cell line
}

\author{
Beth M. Cleveland, ${ }^{1, \dagger}$ Stephen S. Leonard, ${ }^{2}$ Hillar Klandorf ${ }^{1}$ and Kenneth P. Blemings ${ }^{1, *}$ \\ 'Division of Animal and Nutritional Sciences; West Virginia University; Morgantown, WV USA; ${ }^{2}$ Health Effects Laboratory Division; National Institute of Occupational Safety \\ and Health; Morgantown, WV USA \\ †Current address: USDA; Agricultural Research Service; National Center for Cool and Cold Water Aquaculture; Leetown, WV USA
}

Abbreviations: UOX, urate oxidase; SIN-1, 3-morpholinosydnonimine hydrochloride; shRNA, short hairpin RNA; ARP, acidic ribosomal protein; ESR, electron spin resonance

Key words: urate oxidase, RNA interference, oxidative stress, uric acid, SIN-1

Humans, birds, and some primates do not express the uric acid degrading enzyme urate oxidase (UOX) and, as a result, have plasma uric acid concentrations higher than UOX expressing animals. Although high uric acid concentrations are suggested to increase the antioxidant defense system and provide a health advantage to animals without UOX, knockout mice lacking UOX develop pathological complications including gout and kidney failure. As an alternative to the knockout model, RNA interference was used to decrease UOX expression using stable transfection in a mouse hepatic cell line (ATCC, FL83B). Urate oxidase mRNA was reduced $66 \%(\mathrm{p}<0.05)$ compared to wild type, as measured by real time RT-PCR. To determine if UOX knockdown resulted in enhanced protection against oxidative stress, cells were challenged with hexavalent chromium $(\mathrm{Cr}(\mathrm{VI})$ ) or 3-morpholinosydnonimine hydrochloride (SIN-1). Compared to wild type, cells with UOX knockdown exhibited a $37.2 \pm 3.5 \%$ reduction $(\mathrm{p}<0.05)$ in the electron spin resonance $(\mathrm{ESR})$ signal after being exposed to $\mathrm{Cr}(\mathrm{VI})$ and displayed less DNA fragmentation $(\mathrm{p}<0.05)$ following SIN-1 treatment. Cell viability decreased in wild type cells $(\mathrm{p}<0.05)$, but not cells with UOX knockdown, after treatment with SIN-1. These results are consistent with an increased intracellular uric acid concentration and an increased defense against oxidative stress.

\section{Introduction}

In the genomes of both prokaryotes and eukaryotes lies the gene for the uric acid degrading enzyme, urate oxidase (UOX,

*Correspondence to: Kenneth P. Blemings; West Virginia University; PO Box 6108; Morgantown, WV 26506 USA; Tel.: 304.293 .2631 x 4315; Fax: 304.293.2232; Email: kbleming@wvu.edu

Submitted: 02/23/09; Revised: 03/10/09; Accepted: 03/10/09

Previously published online as an Oxidative Medicine and Cellular Longevity E-publication:

http://www.landesbioscience.com/journals/oximed/article/8372
EC 1.7.3.3.), however, not all organisms express this gene. Among those organisms in which its expression is silenced are humans, birds, some primates, terrestrial reptiles and most insects. In these organisms, uric acid is excreted as the terminal product of purine degradation. In UOX expressing animals, UOX further degrades uric acid to allantoin, the terminal product of purine degradation. When UOX is expressed, the plasma concentration of uric acid is much lower than in those animals that do not express the enzyme. For example, in humans the normal range of serum uric acid is 200 to $400 \mu \mathrm{M}$, which is similar to that found in birds ${ }^{1}$ and 10 to 20 times that found in UOX expressing animals. Without UOX, humans have achieved a state of hyperuricemia that approaches the saturation point ${ }^{2,3}$ and, as a result, gout is a prevalent disease in humans.

The association of hyperuricemia with hypertension ${ }^{4}$ and cardiovascular disease (CVD) ${ }^{5}$ in humans, as well as the pathological complications resulting from uric acid crystallization in the kidneys and joints makes the functional advantage of a lack of UOX expression unclear. One widely accepted theory is that increased serum uric acid may provide humans with an increased antioxidant capacity for free radical scavenging, which may reduce the accumulation of oxidative damage and extend the life span. ${ }^{6}$ Supporting this theory is the positive correlation between plasma urate and life span among the primate species. ${ }^{7}$ Also, numerous reports cite the ability of uric acid to protect cellular components from reactive oxygen and nitrogen species, ${ }^{8,9}$ which may contribute to animal longevity. However, uric acid exhibits pro-oxidant ${ }^{10,11}$ and pro-inflammatory ${ }^{12}$ properties when concentrations are elevated, suggesting that hyperuricemia may be involved in the onset and/ or exacerbation of diseases associated with high levels of oxidative stress, like CVD, ${ }^{13,14}$ hypertension ${ }^{15,16}$ and ischemic stroke. ${ }^{17}$

To further understand the potential role that uric acid has in longevity, disease development and disease treatment, a mouse model for hyperuricemia was created that lacks urate oxidase expression. ${ }^{18,19}$ These mice were severely hyperuricemic, exhibiting serum uric acid concentrations ten times higher than that 
found in the wild type mice and twice that found in humans. Uric acid crystals developed in the kidneys and led to urate nephropathy and nephrogenic diabetes insipidus, resulting in dehydration and death of most mice within several weeks of birth. The extreme hyperuricemia and resultant pathological complications obviate the use of these mice, therefore a more appropriate animal model of human hyperuricemia should be established. Using RNA interference to reduce UOX expression in mice may elevate serum uric acid without it reaching the lethal concentrations observed in the knockout model, thereby potentially providing an effective experimental model of human hyperuricemia.

The objective of this study was to utilize RNA interference to "knockdown" UOX expression in a mouse hepatic cell line and to determine the effects on the oxidative stress response. This will provide a direct link between reduced UOX expression and the resultant increased protection this affords from oxidative damage by reactive species. The advantage of using small interfering RNAs is that this approach affords an element of control over UOX gene expression and subsequently the degree to which serum uric acid concentrations are elevated.

\section{Results}

There was a $66 \%$ knockdown in UOX mRNA (Fig. 1) $(\mathrm{p}<0.05)$ in the cell line expressing shRNA sequence 1 . This was the numerically greatest level of UOX knockdown among the cell lines expressing shRNA sequences that target UOX. The reduction of UOX mRNA in the cell lines expressing shRNA sequences 2-4 ranged between $0 \%$ and $60 \%$ of wild type levels (data not shown). No

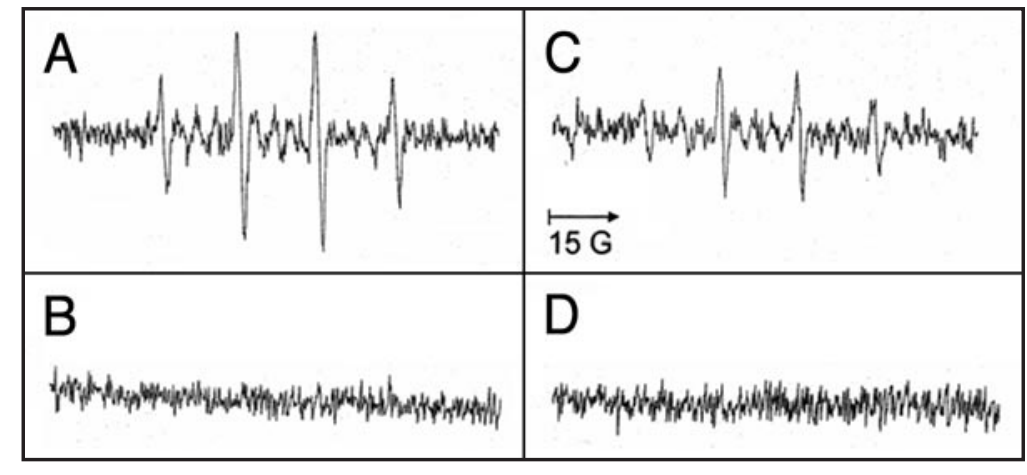

Figure 2. Electron spin resonance in wild type and cells with urate oxidase (UOX) silencing. Spectra (A and B) were generated in the presence of wild type cells and spectra ( $C$ and $D)$ were generated in the presence of cells with urate oxidase knockdown. Only cells in spectra (A and C) were exposed to $\mathrm{Cr}(\mathrm{VI})$ at $200 \mu \mathrm{M}$.

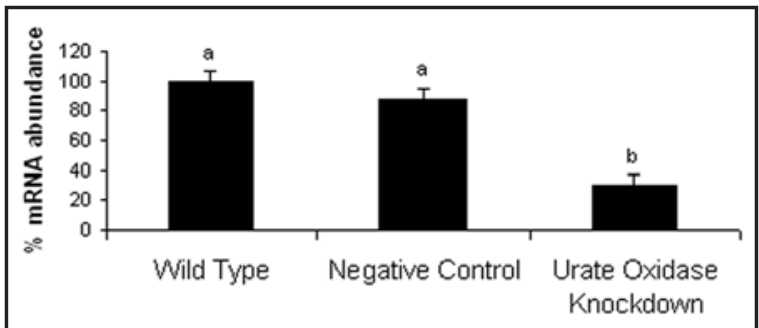

Figure 1. Urate oxidase mRNA abundance in wild type cells, negative control cells, or cells with urate oxidase (UOX) knockdown. Urate oxidase mRNA abundance is scaled to wild type levels, which is set at $100 \%$. Bars represent means \pm SEM, $n=2$. Different letters indicate differences $(p<$ 0.05 ) between cell lines. difference in UOX mRNA abundance between the wild type cell line and the cell line serving as the negative control was detected $(\mathrm{p}>0.05)$.

Representative ESR spectra are shown in Figure 2. This spectrum consists of a 1:2:2:1 quartet with hydrogen and nitrogen splitting constants of $\mathrm{a}_{\mathrm{H}}=\mathrm{a}_{\mathrm{N}}=14.9 \mathrm{G}$. Based on these splitting constants, the quartet was assigned to a $\mathrm{DMPO} / \mathrm{OH}$ adduct, which can also be generated by decomposed superoxide free radicals. There was no measurable signal in cells not exposed to $\mathrm{Cr}(\mathrm{VI})$. When exposed to $\mathrm{Cr}(\mathrm{VI})$, cells with UOX knockdown exhibit a $37 \%$ smaller $(\mathrm{p}<0.05)$ free radical signal than wild type cells.

Data presented in Figure 3 were tested for fit to a linear regression line to determine if SIN-1 exposure had an effect on cell viability. In both the wild type and negative control cell lines, cell viability decreased with increasing concentrations of SIN-1 ( $\mathrm{p}<$ $0.01)$. However, no significant decrease in cell viability occurred in the cell line with UOX knockdown $(\mathrm{p}=0.99)$. Across all cells lines, after 24 hours of exposure to $1,000 \mu \mathrm{M}$ SIN-1, there was no cell survival (data not shown).

Tail length, which was measured in arbitrary units and indicative of the extent of DNA fragmentation, from all cell line by treatment combinations was quantified and is presented in Figure 4. Analysis of variance indicated a main effect of cell line and SIN-1 concentration, as well as a cell line by SIN-1 concentration interaction, on tail length $(\mathrm{p}<0.05)$. Pooled across all cell lines, comet 


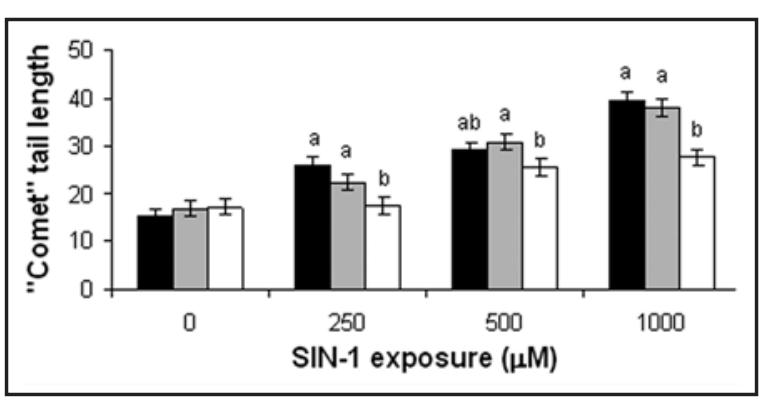

Figure 4. Comet tail length (arbitrary units) of the wild type (black bars), negative control (gray bars) and urate oxidase (UOX) knockdown (white bars) cell lines exposed to various concentrations of 3-morpholinosydnonimine hydrochloride $(\mathrm{SIN}-1)$. Bars represent means $\pm \mathrm{SEM}$. Letters represent significant differences $(p<0.05)$ between cell lines within the same concentration of $\mathrm{SIN}-1$.

SIN-1. The UOX knockdown cells had a significantly shorter tail length $(\mathrm{p}<0.05)$ than both wild type and negative control cells at $250 \mu \mathrm{M}$ and 1,000 $\mu \mathrm{M}$ SIN-1. When exposed to $500 \mu \mathrm{M}$ SIN-1, cells with UOX knockdown had shorter tails $(\mathrm{p}<0.05)$ than only the negative control cell line.

\section{Discussion}

In the present experiment, short interfering RNAs were used to silence UOX mRNA approximately $66 \%$ compared to wild type. Exposure to $\mathrm{Cr}(\mathrm{VI})$ resulted in a less intense ESR signal in cells with UOX silencing, indicative of lower hydroxyl and/or superoxide radical concentrations. In wild type and negative control cells, cell viability decreased with increasing concentrations of the peroxynitrite producing chemical, SIN-1, up to the $500 \mu \mathrm{M}$ level. This relationship was not observed in cells with urate oxidase silencing. The comet assay, used to detect DNA fragmentation induced by SIN-1, indicated that cells with UOX silencing had less DNA denaturation when exposed to SIN-1. These aforementioned findings are consistent with increased protection from oxidative damage in UOX silenced cells.

The effect of reducing UOX mRNA on intracellular uric acid concentrations is unknown. Attempts were made to assess concentration differences but technical difficulties prevented accurate quantification. However, because of existing differences in the physiological responses to oxidative stimuli between the cell lines, it is likely that an increase in the intracellular concentration of uric acid occurred with UOX mRNA silencing. Additionally, neither the transfection conditions nor the expression of the shRNA affected the handling of oxidative stress, since the effects of oxidative stress in the negative control cell line remain similar to wild type cells. Reducing UOX activity levels with oxonic acid, a competitive inhibitor of the enzyme, is effective in increasing circulating uric acid concentrations. ${ }^{20}$ Therefore, assuming the intracellular concentration of uric acid is increased in cells with UOX silencing, these results support the role of uric acid as an antioxidant.

Hexavalent chromium is a carcinogen in both human and animal models. ${ }^{21}$ The most documented evidence of $\mathrm{Cr}(\mathrm{VI})$ toxicity is from inhalation of the molecule, which is most apparent in the increased rate of lung, ${ }^{22}$ kidney, prostrate and bladder cancers $^{23}$ and mental illness ${ }^{22}$ in those exposed in the workplace. Once in the cell, $\mathrm{Cr}(\mathrm{VI})$ is reduced by intracellular antioxidants like glutathione, ascorbic acid and cysteine or through the intermediates $\mathrm{Cr}(\mathrm{V})$ and $\mathrm{Cr}(\mathrm{IV})$ to trivalent chromium $(\mathrm{Cr}(\mathrm{III})){ }^{24}$ Trivalent chromium can interact with DNA to form Cr-DNA adducts, ${ }^{25}$ which can induce apoptosis or mutagenesis. Interaction of the hexavalent chromium with cellular components can induce production of hydroxyl and superoxide free radicals detected by ESR, inducing oxidative stress and causing oxidative damage. ${ }^{26,27}$ The present study indicates that cells with UOX silencing are exposed to less reactive oxygen species than wild type cells when treated with $\mathrm{Cr}(\mathrm{VI})$. This supports an existing theory that, in vitro, uric acid was effective at reducing DNA damage induced by $\mathrm{Cr}$ (III) exposure. ${ }^{28}$ The probable increase in the intracellular concentration of uric acid either contributes to greater free radical scavenging or reduces the rate of free radical production, or a combination of both, thus protecting cellular components from $\mathrm{Cr}(\mathrm{VI})$-induced reactive oxygen species damage. This raises the possibility that uric acid may be a therapeutic agent for $\mathrm{Cr}(\mathrm{VI})$ exposure, a concept that warrants further investigation.

In addition to $\mathrm{Cr}(\mathrm{VI})$, SIN-1 was used in the present experiment to induce oxidative stress. Decomposition of SIN-1 in solution at $\mathrm{pH}>5$ causes production of superoxide and nitric oxide. Together, these chemicals spontaneously form peroxynitrite, which is detected both in the media ${ }^{29}$ and inside cells. ${ }^{30}$ It has been well established in numerous cell types that treating cells with SIN-1 causes intracellular oxidative stress and accumulation of intracellular markers of oxidative damage in a dose-dependent manner, resulting in a reduction in cell viability.

Exposure of human lymphoid blastoma cells to SIN-1 concentrations between $1 \mathrm{mM}$ and $5 \mathrm{mM}$ caused a dose-dependent increase in cell death. ${ }^{31}$ This is supported by data in human premonocytic cells where a reduction in viability was found after treatment of cells with $1 \mathrm{mM}$ and $2 \mathrm{mM}$ SIN-1. ${ }^{32}$ Interestingly, rodent cell culture exhibits a lower tolerance to SIN-1-induced reduction in viability. In the present experiment, wild type cell viability began to decrease when the SIN-1 concentration in the media was $100 \mu \mathrm{M}$ and decreased to approximately $50 \%$ viability when the concentration reached $500 \mu \mathrm{M}$, while a $1 \mathrm{mM}$ concentration resulted in no viable cells after 24 hours. The $50 \%$ reduction in cell viability at $500 \mu \mathrm{M}$ was also observed in rat adrenal gland cell culture. ${ }^{33}$ Biological fluids have a quenching effect on reactive species produced by SIN-1, ${ }^{34}$ so the origin of animal sera used to supplement growth media likely influences SIN-1-induced peroxynitrite exposure.

Incubating cells with antioxidants or antioxidant enzymes reduces the toxicity of SIN-1 in cell culture. Exposure to $1 \mathrm{mM}$ or $5 \mathrm{mM}$ uric acid ${ }^{31,33}$ or a combination of catalase and superoxide dismutase $^{31}$ limited the reduction in cell viability or cell death caused by SIN-1. In the present experiment, the maintenance of cell viability between $100 \mu \mathrm{M}$ and $500 \mu \mathrm{M}$ SIN-1 that occured with UOX silencing supports the concept that intracellular uric acid is increased in these cells, protecting the cellular components from oxidative damage that leads to cell death. 
One of the specific sites of SIN-1 induced oxidative damage is denaturation of genomic DNA. The data presented here agrees with numerous reports utilizing the comet assay as an indicator of DNA damage induced by SIN-1 in human lymph cells ${ }^{29,31}$ and Chinese hamster fibroblasts ${ }^{35}$ that was preventable by inclusion of catalase, ${ }^{29}$ lycopene or $\beta$-carotene ${ }^{35}$ in the cell culture media. The ability of antioxidants or antioxidant enzymes to limit the strand breaks implies that an increased antioxidant capacity is present in cells with UOX silencing and presumably this is an increased uric acid concentration.

As demonstrated in this study, RNA interference can be used in a mouse-derived cell culture system to reduce UOX expression, which resulted in increased protection against oxidative stress. Additionally, the results in the present study suggest that intracellular uric acid concentration was not increased to a level that became pro-oxidative. The next logical experiment would be to apply this concept in a living mouse. The advantage of retaining a certain level of UOX expression, as opposed to eliminating it completely as in the knockout models, is that the elevation of uric acid to lethal levels can be avoided. Therefore, moderate to dramatic increases in circulating uric acid concentrations would likely occur proportional to the degree of UOX knockdown which would allow for further investigation into the role that uric acid may play in disease treatment and prevention.

Several reports have established an association between serum uric acid and death due to cardiac mortality ${ }^{36-38}$ and some evidence indicates that hyperuricemia can predict development of hypertension, ${ }^{39,40}$ obesity, ${ }^{41}$ kidney disease ${ }^{42}$ and diabetes. ${ }^{43,44}$ It has been suggested that treating hyperuricemia with allopurinol in combination with anti-hypertensive drugs and lipid-lowering therapies may synergistically act to reduce the risk of cardiovascular disease. ${ }^{45}$ Additionally, using allopurinol to reduce uric acid exerts beneficial effects on inflammatory indices in patients with ischemic stroke. ${ }^{46,47}$ Therefore, mice exhibiting hyperuricemia via UOX knockdown would help to better understand the associations between uric acid and diseases that are characterized by excessive oxidative stress.

\section{Materials and Methods}

Plasmid construction. Plasmid pSilencer4.1-CMVneo (Ambion, Austin, TX), was selected for stable expression of short hairpin RNA (shRNA) sequences in mammalian cells while conferring resistance to antibiotics. Sequences used for RNA interference were generated against mouse UOX and the following four sense sequences were chosen (1) 5'-AGC CUU CCG AAC AUU CAC U-3', (2) 5'-ACC UCA AGG UCU UGA AAA C-3', (3) 5'-GGA CUG AUC AAC AAG GAA G-3' and (4) 5'-ACC UAC ACG GUG AUA AUU C-3'. The loop sequence, TTCAAGAGA, joined the sense and antisense sequences in the hairpin structure. An additional "scrambled" shRNA sequence that was designed by Ambion to have limited similarity to the mouse genome database served as a negative control and was ligated into pSilencer4.1-CMVneo.

Cell culture and transfection conditions. A mouse hepatic cell line was purchased from ATCC (designation: FL83B, Manasass, VA) and grown per supplier's instructions in F-12K media (ATCC,
Manasass, VA) supplemented with $10 \%$ fetal bovine serum and 500 I.U. penicillin $/ \mathrm{mL}$, and $500 \mu \mathrm{g}$ streptomycin $/ \mathrm{mL}$. On the day of transfection, $6 \times 10^{4}$ cells were plated per well with antibioticfree growth media in a 24-well plate with $48.5 \mu \mathrm{L}$ Opti-MEM media (Invitrogen), $1.5 \mu \mathrm{L} \mathrm{XP-sport} \mathrm{(Ambion)} \mathrm{and} 0.5 \mu \mathrm{g}$ pSilencer4.1-CMVneo with the shRNA to either UOX or the nonsense sequence per transfection reagent protocol. The transfection was completed for each of the four shRNA sequences for UOX knockdown and the nonsense shRNA sequence. Six hours posttransfection, the media was replaced with antibiotic containing growth media. Twenty-four hours post-transfection, cells were expanded to a $60-\mathrm{mm}$ cell culture dish with growth media supplemented with $900 \mu \mathrm{g} \mathrm{G418/mL} \mathrm{media.} \mathrm{Cells} \mathrm{were} \mathrm{exposed} \mathrm{to} \mathrm{G418}$ and surviving colonies were selected and expanded.

Real time RT-PCR. Real time RT-PCR was used to analyze mRNA knockdown in cell lines using acidic ribosomal protein (ARP) as a reference gene. A T-75 flask of cells was washed with $5 \mathrm{~mL}$ of cold Hanks balanced salt solution and layered with $3 \mathrm{~mL}$ Trizol LS (Invitrogen) and RNA was isolated according to manufacturer's protocol. RNA was quantified and the quality was determined using $A_{260}: A_{280}$. Two $\mu \mathrm{g}$ of RNA was reverse transcribed using oligo-dT primers (Promega) and MMLV (Promega) per manufacturer's protocol. Complementary DNA was diluted 1:4 with nuclease free water and $10 \mu \mathrm{L}$ (for UOX PCR) or $5 \mu \mathrm{L}$ (for ARP PCR) was used in a $50 \mu \mathrm{L}$ PCR reaction with $25 \mu \mathrm{L}$ 2X SYBR Green Supermix (BioRad, Hercules, CA), $1.25 \mu \mathrm{M}$ forward ARP primer (5'-CAA CCC AGC TCT GGA GAA AC-3') and $1.25 \mu \mathrm{M}$ reverse ARP primer (5'-GTG AGG TCC TCC TTG GTG AA-3') or $1.25 \mu \mathrm{M}$ forward UOX primer (5'-TGG AGA CTT CAA CGG CTT CT-3') and $1.25 \mu \mathrm{M}$ reverse UOX primer (5'-TGG CCC ATA GAT CTC CTT TG-3'). The real time RT-PCR protocol was performed on a BioRad iCycler IQ Detection System (Hercules, CA). The protocol began with a "hot-start" at $95^{\circ} \mathrm{C}$ for 5 minutes, followed by a cycle of $95^{\circ} \mathrm{C}$ for 15 seconds, $60^{\circ} \mathrm{C}$ for 30 seconds and $72^{\circ} \mathrm{C}$ for 30 seconds. The cycle was completed forty times, followed by melt curve analysis. Real-time RT-PCR data was analyzed using the efficiency corrected relative expression method. ${ }^{48}$ The cell line demonstrating the greatest UOX knockdown, the negative control cell line, and the wild type cell line were used in subsequent experiments to investigate the oxidative stress response.

Electron spin resonance. Electron spin resonance (ESR) spin trapping was used to detect short-lived reactive oxygen intermediates using an established method. ${ }^{49}$ All ESR measurements were conducted using a Bruker EMX spectrometer (Bruker Instruments Inc., Billerica, MA) with a flat cell assembly and an Acquisit program was used for data acquisition and analysis. The ESR spectrometer settings were: receiver gain, $5.02 \times 10^{4}$; time constant, $40.96 \mathrm{~ms}$; modulation amplitude, $0.50 \mathrm{G}$; scan time, $41.94 \mathrm{~s}$; magnetic field $3480 \pm 100 \mathrm{G}$. Experiments were performed at room temperature, under ambient air. Signal intensity was quantified by measuring average distance $(\mathrm{mm})$ using the peak to peak method. Each sample $(500 \mu \mathrm{L})$ contained $5 \times 10^{5}$ cells in phosphate buffered saline, $200 \mathrm{mM}$ 5,5-dimethyl-1-pyrroline- $\mathrm{N}$-oxide (DMPO), and 0.0 or $200 \mu \mathrm{M}$ hexavalent chromium $(\mathrm{Cr}(\mathrm{VI}))$ to 
induce radical formation. Samples $(\mathrm{n}=5)$ were incubated for $37^{\circ} \mathrm{C}$ for five minutes before loading into the flat cell assembly for free radical detection.

Cell viability. Cell viability was used to determine the ability of the cells to survive a reactive nitrogen species challenge. On day one, $1 \times 10^{4}$ cells were plated in a well of a 96-well plate and grown overnight. On day two, duplicate wells, the media was replaced with $100 \mu \mathrm{L}$ media containing various concentrations of 3-morpholinosydnonimine hydrochloride (SIN-1). After 24 hours of SIN-1 exposure the cell viability was determined using the MTT assay (Cayman Chemical, Ann Arbor, MI) per manufacturer's protocol.

DNA fragmentation. Cells were seeded, $1.5 \times 10^{5}$ per well, in a 12-well plate and allowed to grow overnight. On day two, media was replaced with media that contained various concentrations of SIN-1. After three hours, cells were harvested and resuspended in $500 \mu \mathrm{L}$ of ice-cold PBS. Fragmented DNA was detected using the Comet Assay per manufacturer's protocol (Trevigen, Gaithersburg, $\mathrm{MD})$. The extent of DNA fragmentation was determined by measuring tail length beginning at center of the cells to the left rim of SYBR green fluorescence using Optimas 6.5 Image analysis software (Media Cybernetics, Silver Spring, MD).

Statistics. Data were analyzed by linear regression analysis or analysis of variance with PC-SAS general linear models procedure for significant differences among treatment means. In the event of a significant $F$ value, the LSD procedure was used for means comparisons. Differences were considered significant at $\mathrm{p}<0.05$.

\section{Acknowledgements}

Thank you to Juanita Engels for her technical expertise. Grant support comes from WV Agriculture and Forestry Experiment Station H413. This is paper 3030 of the WV Agricultural and Forestry Experiment Station.

\section{References}

1. Tsahar E, Arad Z, Izhaki I, Guglielmo CG. The relationship between uric acid and its oxidative product allantoin: A potential indicator for the evaluation of oxidative stress in birds. J Comp Physiol [B] 2006; 176:653-61.

2. Christen P, Peacock WC, Christen AE, Wacker WE. Urate oxidase in primate phylogenesis. Eur J Biochem 1970; 12:3-5.

3. Friedman TB, Polanco GE, Appold JC, Mayle JE. On the loss of uricolytic activity during primate evolution-I. Silencing of urate oxidase in a hominoid ancestor. Comp Biochem Physiol B 1985; 81:653-9.

4. Schachter M. Uric acid and hypertension. Curr Pharm Des 2005; 11:4139-43.

5. Wannamethee SG. Serum uric acid and risk of coronary heart disease. Curr Pharm Des 2005; 11:4125-32.

6. Ames BN, Cathcart R, Schwiers E, Hochstein P. Uric acid provides an antioxidant defense in humans against oxidant- and radical-caused aging and cancer: A hypothesis. Proc Natl Acad Sci USA 1981; 78:6858-62.

7. Cutler RG. Urate and ascorbate: their possible roles as antioxidants in determining longevity of mammalian species. Arch Gerontol Geriatr 1984; 3:321-48.

8. Becker BF. Towards the physiological function of uric acid. Free Radic Biol Med 1993; 14:615-31.

9. Glantzounis GK, Tsimoyiannis EC, Kappas AM, Galaris DA. Uric acid and oxidative stress. Curr Pharm Des 2005; 11:4145-51.

10. Abuja PM. Ascorbate prevents prooxidant effects of urate in oxidation of human low density lipoprotein. FEBS Lett 1999; 446:305-8.

11. Stinefelt B, Leonard SS, Blemings KP, Shi X, Klandorf H. Free radical scavenging, DNA protection and inhibition of lipid peroxidation mediated by uric acid. Ann Clin Lab Sci 2005; 35:37-45.

12. Kanellis J, Watanabe S, Li JH, Kang DH, Li P, Nakagawa T, et al. Uric acid stimulates monocyte chemoattractant protein-1 production in vascular smooth muscle cells via mitogen-activated protein kinase and cyclooxygenase-2. Hypertension 2003; 41:1287-93.
13. Strasak A, Ruttmann E, Brant L, Kelleher C, Klenk J, Concin H, et al. Serum uric acid and risk of cardiovascular mortality: A prospective long-term study of 83,683 Austrian men. Clin Chem 2008; 54:273-84

14. Strasak AM, Kelleher CC, Brant LJ, Rapp K, Ruttmann E, Concin H, et al. Serum uric acid is an independent predictor for all major forms of cardiovascular death in 28,613 elderly women: A prospective 21-year follow-up study. Int J Cardiol 2008; 125:232-9.

15. Bainbridge SA, Roberts JM. Uric acid as a pathogenic factor in preeclampsia. Placenta 2008; 29:67-72.

16. Forman JP, Choi H, Curhan GC. Uric acid and insulin sensitivity and risk of incident hypertension. Arch Intern Med 2009; 169:155-62.

17. Milionis HJ, Kalantzi KJ, Goudevenos JA, Seferiadis K, Mikhailidis DP, Elisaf MS Serum uric acid levels and risk for acute ischaemic non-embolic stroke in elderly subjects. J Intern Med 2005; 258:435-41.

18. Wu X, Wakamiya M, Vaishnav S, Geske R, Montgomery C Jr, Jones P, et al. Hyperuricemia and urate nephropathy in urate oxidase-deficient mice. Proc Natl Acad Sci USA 1994; 91:742-6.

19. Kelly SJ, Delnomdedieu M, Oliverio MI, Williams LD, Saifer MG, Sherman MR, et al. Diabetes insipidus in uricase-deficient mice: A model for evaluating therapy with poly(ethylene glycol)-modified uricase. J Am Soc Nephrol 2001; 12:1001-9.

20. Roncal CA, Mu W, Croker B, Reungjui S, Ouyang X, Tabah-Fisch I, et al. Effect of elevated serum uric acid on cisplatin-induced acute renal failure. Am J Physiol Renal Physiol 2007; 292:116-22.

21. Costa M, Klein CB. Toxicity and carcinogenicity of chromium compounds in humans. Crit Rev Toxicol 2006; 36:155-63.

22. Gibb HJ, Lees PS, Pinsky PF, Rooney BC. Lung cancer among workers in chromium chemical production. Am J Ind Med 2000; 38:115-26.

23. Cohen MD, Kargacin B, Klein CB, Costa M. Mechanisms of chromium carcinogenicity and toxicity. Crit Rev Toxicol 1993; 23:255-81.

24. Zhitkovich A. Importance of chromium-DNA adducts in mutagenicity and toxicity of chromium(VI). Chem Res Toxicol 2005; 18:3-11.

25. Zhitkovich A, Voitkun V, Costa M. Glutathione and free amino acids form stable complexes with DNA following exposure of intact mammalian cells to chromate. Carcinogenesis 1995; 16:907-13.

26. Leonard SS, Vallyathan V, Castranova V, Shi X. Generation of reactive oxygen species in the enzymatic reduction of $\mathrm{PbCrO} 4$ and related DNA damage. Mol Cell Biochem 2002; 234:309-15.

27. Ding M, Shi X. Molecular mechanisms of $\mathrm{Cr}(\mathrm{VI})$-induced carcinogenesis. Mol Cell Biochem 2002; 234:293-300.

28. Burkhardt S, Reiter RJ, Tan DX, Hardeland R, Cabrera J, Karbownik M. DNA oxidatively damaged by chromium(III) and $\mathrm{H}(2) \mathrm{O}(2)$ is protected by the antioxidants melatonin, N(1)-acetyl-N(2)-formyl-5-methoxykynuramine, resveratrol and uric acid. Int J Biochem Cell Biol 2001; 33:775-83.

29. Doulias PT, Barbouti A, Galaris D, Ischiropoulos H. SIN-1-induced DNA damage in isolated human peripheral blood lymphocytes as assessed by single cell gel electrophoresis (comet assay). Free Radic Biol Med 2001; 30:679-85.

30. Saito S, Yamamoto-Katou A, Yoshioka H, Doke N, Kawakita K. Peroxynitrite generation and tyrosine nitration in defense responses in tobacco BY-2 cells. Plant Cell Physiol 2006; 47:689-97.

31. Li CQ, Trudel LJ, Wogan GN. Genotoxicity, mitochondrial damage and apoptosis in human lymphoblastoid cells exposed to peroxynitrite generated from SIN-1. Chem Res Toxicol 2002; 15:527-35.

32. Yang ES, Park JW. Antioxidant enzyme inhibitors enhance peroxynitrite-induced cell death in U937 cells. Mol Cell Biochem 2007; 301:61-8.

33. Choi WT, Youn YC, Han ES, Lee CS. Protective effect of 1-methylated $\beta$-carbolines against 3-morpholinosydnonimine-induced mitochondrial damage and cell viability loss in PC12 cells. Neurochem Res 2004; 29:1807-16.

34. Pascual C, Reinhart K. Effect of antioxidants on induction time of luminol luminescence elicited by 3-morpholinosydnonimine (SIN-1). Luminescence 1999; 14:83-9.

35. Muzandu K, Ishizuka M, Sakamoto KQ, Shaban Z, El Bohi K, Kazusaka A, Fujita S. Effect of lycopene and beta-carotene on peroxynitrite-mediated cellular modifications. Toxicol Appl Pharmacol 2006; 215:330-40.

36. Ekundayo OJ, Dell'italia LJ, Sanders PW, Arnett D, Aban I, Love TE, et al. Association between hyperuricemia and incident heart failure among older adults: A propensitymatched study. Int J Cardiol 2009.

37. Chen JH, Chuang SY, Chen HJ, Yeh WT, Pan WH. Serum uric acid level as an independent risk factor for all-cause, cardiovascular and ischemic stroke mortality: A chinese cohort study. Arthritis Rheum 2009; 61:225-32.

38. Gagliardi AC, Miname MH, Santos RD. Uric acid: A marker of increased cardiovascular risk. Atherosclerosis 2009; 202:11-7.

39. Alper AB Jr, Chen W, Yau L, Srinivasan SR, Berenson GS, Hamm LL. Childhood uric acid predicts adult blood pressure: The Bogalusa Heart Study. Hypertension 2005; 45:34-8.

40. Dyer AR, Liu K, Walsh M, Kiefe C, Jacobs DR Jr, Bild DE. Ten-year incidence of elevated blood pressure and its predictors: the CARDIA study. Coronary Artery Risk Development in (Young) Adults. J Hum Hypertens 1999; 13:13-21. 
41. Masuo K, Kawaguchi H, Mikami H, Ogihara T, Tuck ML. Serum uric acid and plasma norepinephrine concentrations predict subsequent weight gain and blood pressure elevation. Hypertension 2003; 42:474-80.

42. Iseki K, Oshiro S, Tozawa M, Iseki C, Ikemiya Y, Takishita S. Significance of hyperuricemia on the early detection of renal failure in a cohort of screened subjects. Hypertens Res 2001; 24:691-7.

43. Nakanishi N, Okamoto M, Yoshida H, Matsuo Y, Suzuki K, Tatara K. Serum uric acid and risk for development of hypertension and impaired fasting glucose or Type II diabetes in Japanese male office workers. Eur J Epidemiol 2003; 18:523-30.

44. Dehghan A, van Hoek M, Sijbrands EJ, Hofman A, Witteman JC. High serum uric acid as a novel risk factor for type 2 diabetes. Diabetes Care 2008; 31:361-2.

45. Dawson J, Quinn T, Walters M. Uric acid reduction: A new paradigm in the management of cardiovascular risk? Curr Med Chem 2007; 14:1879-86.

46. Muir SW, Harrow C, Dawson J, Lees KR, Weir CJ, Sattar N, Walters MR. Allopurinol use yields potentially beneficial effects on inflammatory indices in those with recent ischemic stroke: A randomized, double-blind, placebo-controlled trial. Stroke 2008; 39:3303-7.

47. Khan F, George J, Wong K, McSwiggan S, Struthers AD, Belch JJ. Allopurinol treatment reduces arterial wave reflection in stroke survivors. Cardiovasc Ther 2008; 26:247-52.

48. Pfaffl MW. A new mathematical model for relative quantification in real-time RT-PCR Nucleic Acids Res 2001; 29:45.

49. Leonard S, Wang S, Zang L, Castranova V, Vallyathan V, Shi X. Role of molecular oxygen in the generation of hydroxyl and superoxide anion radicals during enzymatic $\mathrm{Cr}(\mathrm{VI})$ reduction and its implication to $\mathrm{Cr}(\mathrm{VI})$-induced carcinogenesis. J Environ Pathol Toxicol Oncol 2000; 19:49-60. 


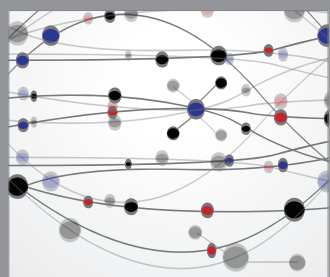

The Scientific World Journal
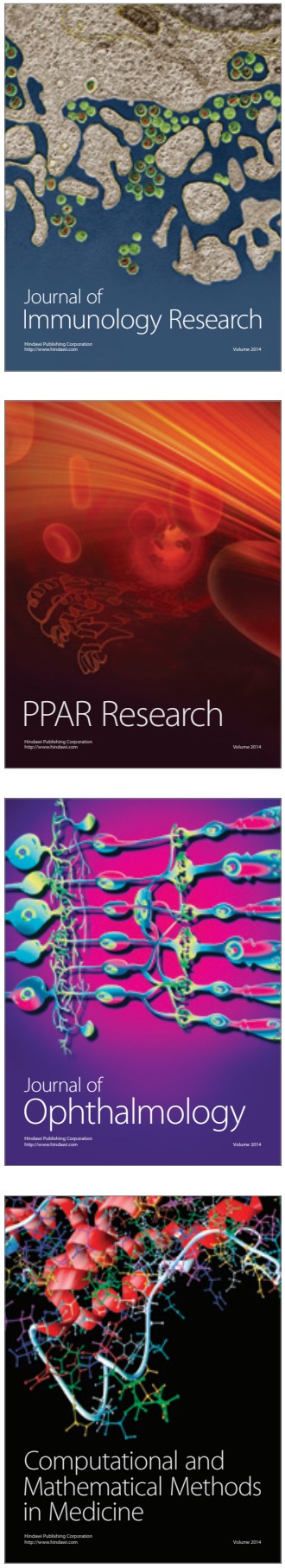

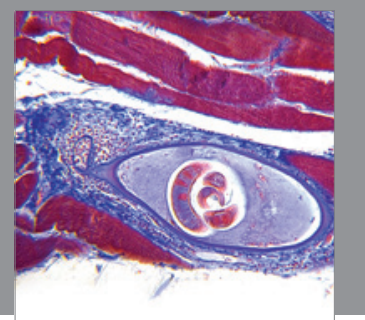

Gastroenterology

Research and Practice
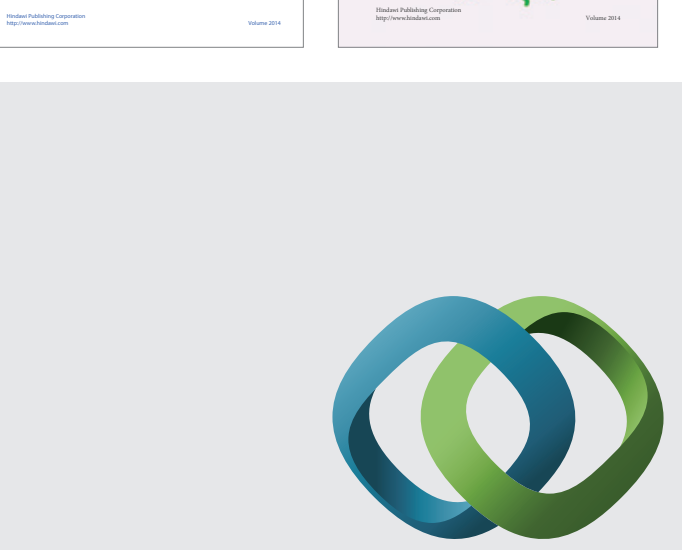

\section{Hindawi}

Submit your manuscripts at

http://www.hindawi.com
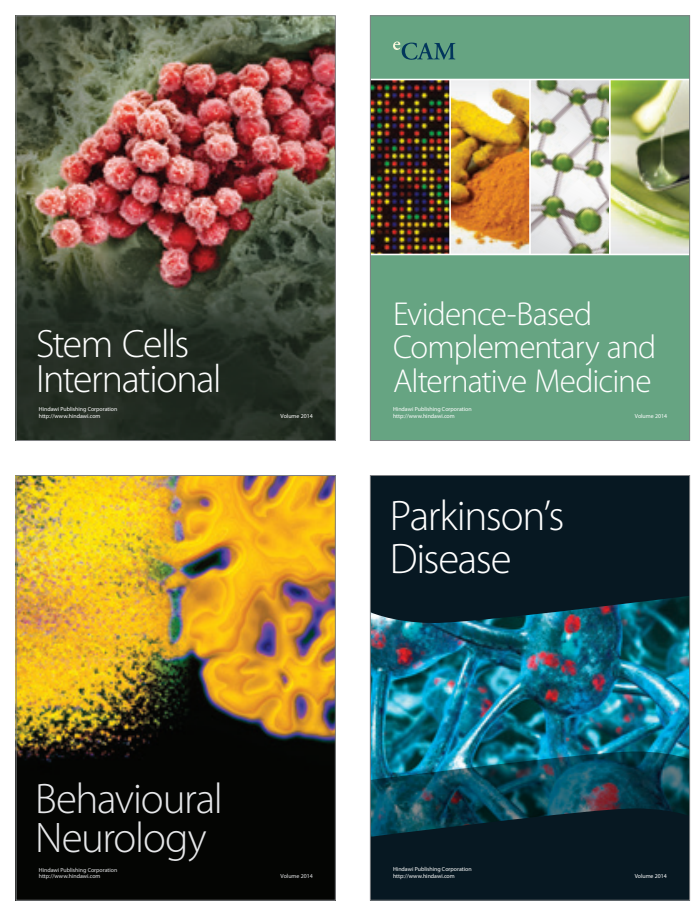

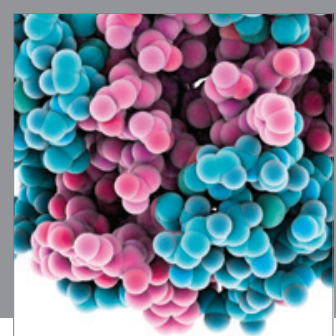

Journal of
Diabetes Research

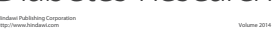

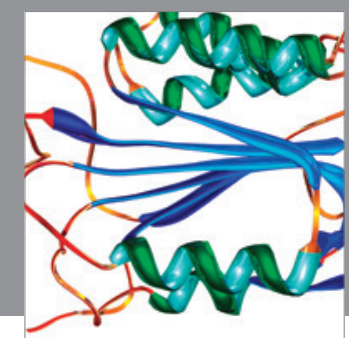

Disease Markers
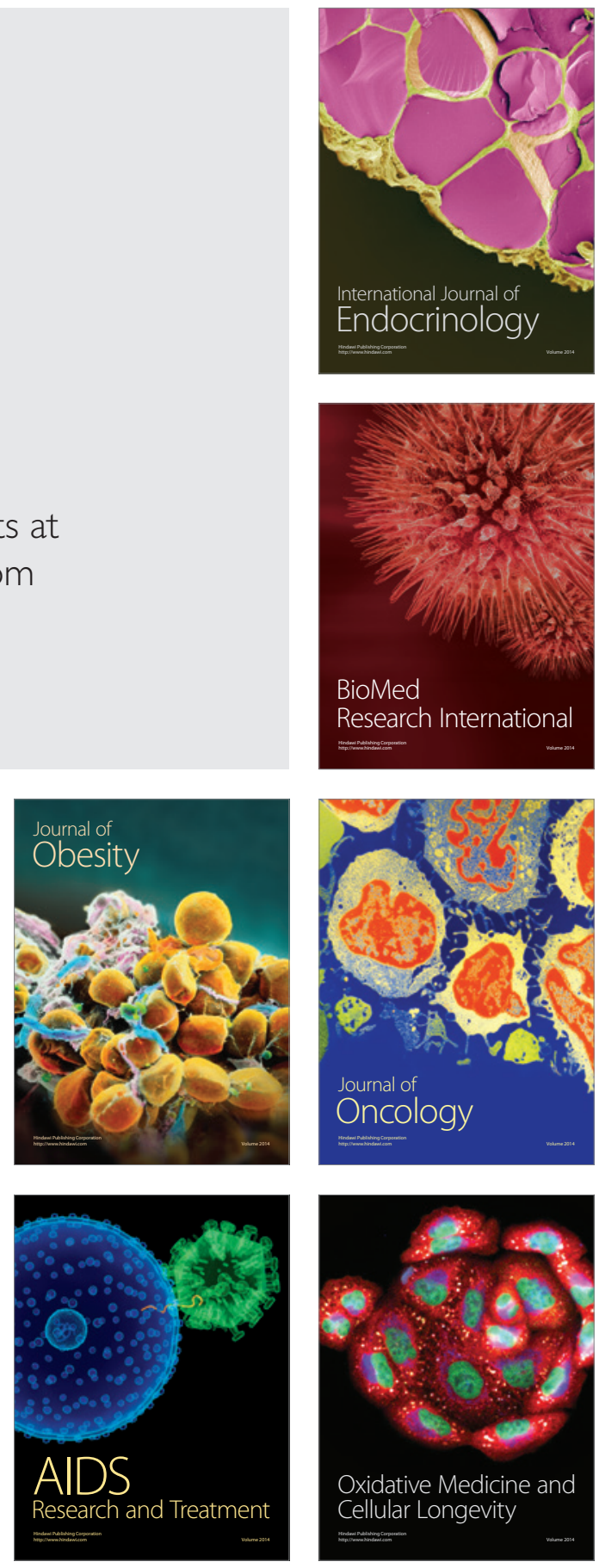